УДК: 336.76

JEL classification: C53, C61

Кривда О.В.

ORCID ID: 0000-0003-4398-6298

канд. економ. наук, дочент

Сидоренко Ю.В.

ORCID ID: 0000-0002-1953-0410

канд. техн. наук, дочент

Романова Д.П.

Наиіональний технічний університет України «Київський політехнічний інститут імені Ігоря Сікорського»

\title{
ПРОГНОЗУВАННЯ ДИНАМІКИ ЕКОНОМІЧНИХ ПРОЦЕСІВ ЗА ДОПОМОГОЮ МЕТОДІВ ФРАКТАЛЬНОЇ ГЕОМЕТРІЇ
}

\section{ПРОГНОЗИРОВАНИЕ ДИНАМИКИ ЭКОНОМИЧЕСКИХ ПРОЦЕССОВ С ПОМОЩЬЮ МЕТОДОВ ФРАКТАЛЬНОЙ ГЕОМЕТРИИ}

\section{FORECASTING THE DYNAMICS OF ECONOMIC PROCESSES BY THE METHODS OF FRACTAL GEOMETRY}

У результаті проведеного дослідження було проаналізовано методи прогнозування динаміки економічних процесів. Проведений аналіз показав, щуо деякі процеси не підлягають прогнозуванню класичними поліноміальними методами. Було виявлено, щзо такі процеси мають фрактальну структуру, $i$ для їх моделювання необхідно розробляти, вдосконалювати та застосовувати комп'ютерні технології фрактальної геометрії. Для усунення недоліків існуючих методів екстраполяції та побудови моделі, щзо за короткий час відтворювала б реальну картину подій, та з високою вірогідністю давала прогноз на наступний період, було удосконалено метод плаваючої середньої иляхом автоматичного підбору конкретного методу на кожній ітерації. Було оцінено сумарні середньоквадратичні похибки розрахунків різними методами плаваючої середньої. Виявилося, що удосконалений метод плаваючої середньої дає найменшу похибку. Створена комп'ютерно-інформаційна система значно спрощує прочес прийняття рішень, що пов'язані з регулюванням стану соціально-економічної сфери в державі, зокрема, зі зменшенням валютних ризиків.

Ключові слова: фрактал, фрактальна розмірність, прогнозування, метод плаваючих середніх, валютні коливання.

B результате проведенного исследования были проанализировань методы прогнозирования динамики социально-экономических процессов. Проведенный анализ показал, что некоторые прочессы не подлежат прогнозированию классическими полиномиальными методами. Было обнаружено, что такие прочессы имеют фрактальную структуру, и для их моделирования необходимо разрабатывать, совершенствовать и применять компьютерные технологии фрактальной геометрии. Для устранения недостатков существуюших методов экстраполяции и построения модели, которая за короткий срок воспроизводила бы реальную картину событий, и с высокой вероятностью давала прогноз на следуюший период, был усовершенствован метод плавающей средней путем автоматического подбора конкретного метода на каждой итераџии. Были оценень суммарные среднеквадратичные погрешности расчетов различными методами плавающей средней. Оказалось, что усовершенствованный 
метод плавающей средней дает наименьшую погрешность. Созданная компьютерноинформачионная система значительно упрощает прочесс принятия решений, связанных с регулированием состояния сочиально-экономической сферы в государстве, в частности, с уменьшением валютных рисков.

Ключевые слова: фрактал, фрактальная размерность, прогнозирование, метод плавающих средних, валютные колебания.

As a result, the study analyzed the forecasting methods of the dynamics of socio-economic processes. The analysis showed that some processes cannot be studied classical polynomial methods of forecasting. It was found that these processes have fractal structure, and for their modeling is necessary to design, develop and apply computer technology fractal geometry. To address the shortcomings of existing methods of extrapolation and model building, which in a short time would reproduce the real picture of the events and is highly likely to give the forecast for the next period, was improved method for average floating through automatic selection of the method at each iteration. Evaluation was made of the total rms error calculation various methods floating average. It was found that the improved method of floating average gives the smallest error. The computer information system simplifies the decision making process related to the regulation of the socio-economic sphere in the country, particularly with decreasing currency risks.

Keywords: fractal, fractal dimension, forecasting, floating average method, currency fluctuations.

Вступ. Проблема дослідження сутності соціально-економічних процесів, аналізу та прогнозування їх динаміки є достатньо відомою проблемою. 3 усього різноманіття процесів по функціональному принципу можна виділити соціальноекономічні та політичні процеси. Їх можна визначити як зміни в суспільстві, які впливають на його добробут, політичну та економічну стабільності, умови безпеки тощо. Обидва процеси взаємопов’ язані.

У зв’язку з тим, що соціально-економічні системи мають дуже складну структуру та поведінку, виникає необхідність використовувати спеціальні методи моделювання та прогнозування, щоб відтворити як можна точніше їх властивості. Практично всі економічні процеси мають хвилеподібний характер, і проблема пояснення природи цього явища нині існує. Одним із шляхів іiі розв'язання може бути дослідження мікроциклів, які існують в господарських системах будь-якого рівня. Для цього досить графічно представити прискорення руху будь-якого показника, що характеризує той чи інший аспект господарської діяльності системи в часі, щоб побачити циклічність досліджуваного процесу.

Джерело розвитку класичного технічного аналізу бере свій початок у XVIII столітті, його принципи були відкриті в Японії. Поступово декілька основних прийомів аналізу історичних цін та прогнозування їх динаміки на основі графіків почали використовуватися в США. Одним з основних дослідникыв фінансового ринку є Чарльз Доу, його ідеї лягли в основу постулатів цього аналізу.

Дослідження можливості використання фрактальної розмірності для аналізу економічних показників проводили Мерфі, У.Шарп; вперше це поняття було введене Хаусдорфом. Застосування теорії хаосу в прогнозуванні курсів валют розглядали М.В. Чекулаєв [4], В.М. Якимкін [5]. Але тему використання фрактального аналізу в прогнозуванні валютних курсів потрібно вважати 
недостатньо вивченою. Сьогодні не розроблено єдиного загальноприйнятого підходу до аналізу та прогнозуванню валютних курсів.

Постановка завдання. Дослідження присвячене обгрунтуванню необхідності розвитку способів прогнозування динаміки економічних процесів за допомогою фрактальної геометрії. Проаналізовано існуючі класичні методи екстраполяції, виявлені їх недоліки. Обчислено фрактальну розмірність графіку коливань курсу валют. Удосконалено метод плаваючої середньої для більш точного прогнозування динаміки зміни валютного курсу.

Методологія. Методологічною та теоретичною основою дослідження $\mathrm{\epsilon}$ методи дедуктивного та індуктивного аналізу, наукової абстракції, порівняльний, системний аналіз, методи математичного та імітаційного моделювання. Поставлені задачі розв'язувались математичними методами, методами геометричного моделювання, методами обчислення розмірності фракталу, екстраполяційними методами, методами перевірки наукових гіпотез за рахунок проведення комп'ютерного експерименту, для чого було розроблено програмну систему. Для розрахунку зміни курсу долара були використані наступні методи: метод найменших квадратів, апроксимаційні методи Гауса та його модифікації (параметричний та сумарний) та інші.

Результати дослідження. Значення моделювання як методу досліджень визначається тим, що модель являє собою концептуальний інструмент, що орієнтований на аналіз процесів, що вивчаються, та їх прогнозування.

Найбільш розповсюдженими $є$ такі типи моделювання, як системне та імітаційне. Імітаційне моделювання $\epsilon$ найкращим інструментом дослідження складних систем, керування якими пов'язане з прийняттям управлінських рішень в умовах невизначеності. У порівнянні з іншими методами моделювання він дає можливість розглянути більшу кількість альтернативних варіантів, i, тим самим, точніше спрогнозувати наслідки прийняття тих чи інших управлінських рішень, забезпечуючи можливість уникнути небажаних наслідків і підвищити позитивний ефект від рішень, що приймаються. Це робить імітаційне моделювання надзвичайно важливим при дослідженні таких складних об'єктів, як соціальноекономічні процеси, безпосереднє «експериментування» над якими загрожує тяжкими, а іноді й непоправними наслідками.

Використання моделей дає можливість проводити прогнозування стану та динаміки процесів та систем. Прогноз - це наукове узагальнене твердження про можливий стан об'єкта в майбутньому, про альтернативні шляхи та терміни їх існування. Е. Янч дав коротке визначення прогнозу: прогноз - це ймовірнісне твердження про майбутнє 3 високим рівнем достовірності [1]. Згідно 3 визначенням, прогнозування - це спосіб наукового передбачення, в якому використовується як минулий накопичений досвід, так і поточні припущення на рахунок майбутнього з метою його визначення. 


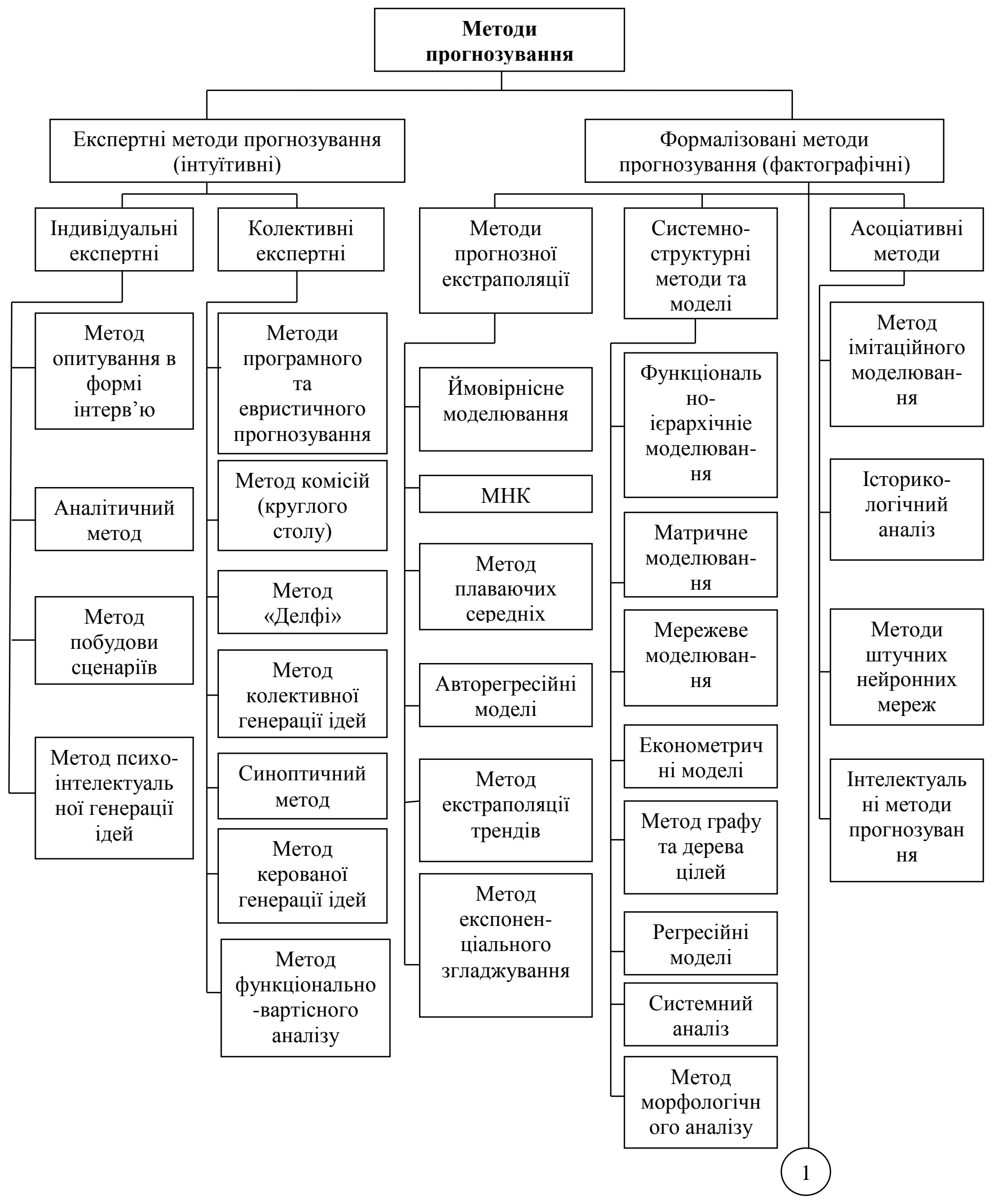

Рис. 1. Сучасна класифікація методів прогнозування 


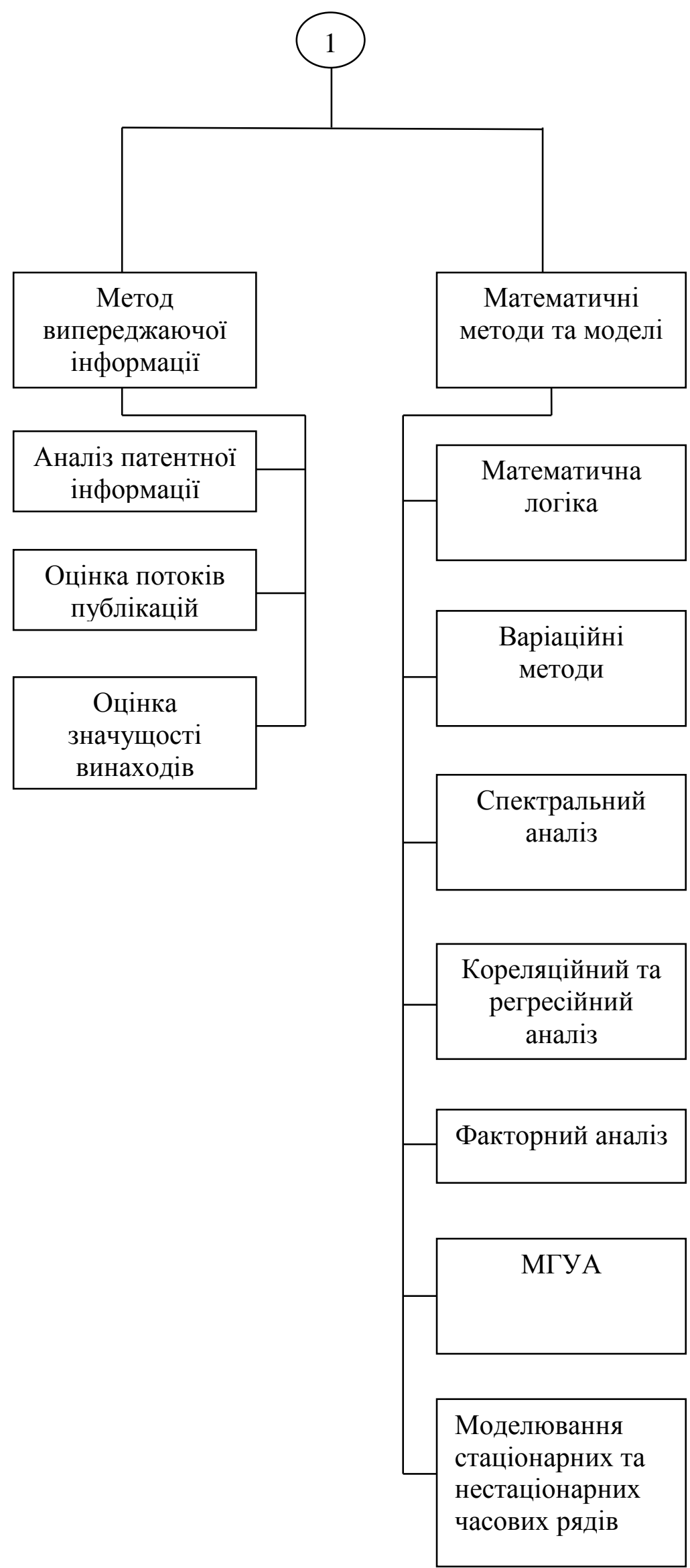

Рис. 2. Сучасна класифікація методів прогнозування 
У багатьох випадках ні один 3 методів сам по собі не може забезпечити необхідну ступінь вірогідності i точності прогнозу, але, якщо він буде використаний в певних поєднаннях з іншими, виявляється досить ефективним переваги одного методу компенсують недоліки іншого, або вони використовуються в розвитку.

У "Робочій книзі з прогнозування" наводиться трирівнева класифікація основних методів прогнозування. У свою чергу кожен рівень у схемі визначається своєю класифікаційною ознакою: ступенем формалізації, загальним принципом дії, способом отримання прогнозної інформації [2].

3 позицій загального підходу сукупність методів прогнозування, спрямованих на вирішення прикладних завдань аналізу стану об'єкта та прогнозу його розвитку в даний час, може бути представлена в класифікації (рис. 1, 2).

Особливе місце в класифікації методів прогнозування займають комбіновані методи, які об'єднують різні методи прогнозування. Використання комбінованих методів особливо актуально для складних соціально-економічних систем, коли при розробці прогнозу показників кожного елемента системи можуть бути використані різні сполучення методів прогнозування. Різновидом комбінованих методів можна вважати економетричне моделювання.

Всі методи прогнозування претендують на універсальність застосування у будь-яких умовах. В дійсності, вони показують достовірні результати лише на певних ділянках часового ряду. Таким чином, низька достовірність існуючих методів аналізу обумовлена тим, що вони не враховують змішану природу економічних показників, зокрема валютних курсів.

Враховуючи основні недоліки сучасних методів прогнозування, виникла необхідність у виявленні інших підходів щодо геометричного (фрактального) моделювання та прогнозування стану та ймовірних напрямків розвитку соціальноекономічних процесів.

Великий досвід математичного моделювання динамічних (еволюційних) процесів, накопичений в світі в останні десятиріччя, розширив та змінив уявлення про адекватність існуючих математичних моделей суті цих процесів.

Класичного арсеналу математичного моделювання, що застосовується валютними аналітиками, який базується на так званій лінійній парадигмі (малі коливання вхідних даних системи в малому ступені міняють іiі траєкторію), в багатьох випадках явно недостатньо для побудови адекватних математичних моделей. Цей факт визначив необхідність фундаментального перегляду лінійної концепції та перехід до так званої нелінійної парадигми в математичному моделюванні (малі коливання вхідних даних чи значень змінних динамічної системи можуть в катастрофічно великому степені змінювати їі траєкторію в силу складності самої системи та хаотичності іiі поведінки). Практична цінність описаної парадигми полягає в тому, що на іï базі вдається більш адекватно відображати специфічні характеристики ієрархічності, конкретної динаміки та високого ступені невизначеності, що притаманні реальним соціальним, економічним, фінансовим, фізичним та іншим процесам та системам [10]. Перехід 
на нову концепцію обумовив необхідність створення принципово нових інструментальних засобів математичного моделювання, зокрема таких, як фрактальну геометрію та фрактальний аналіз.

Для графіку коливань курсу валют було визначено фрактальну розмірність (рис. 3). Вона склала 1.333, що свідчить про те, що на систему впливає одна або кілька сил, що рухають систему в одному напрямку. Отже, використання фрактальних методів для моделювання та прогнозування динаміки економічних процесів є доцільним.

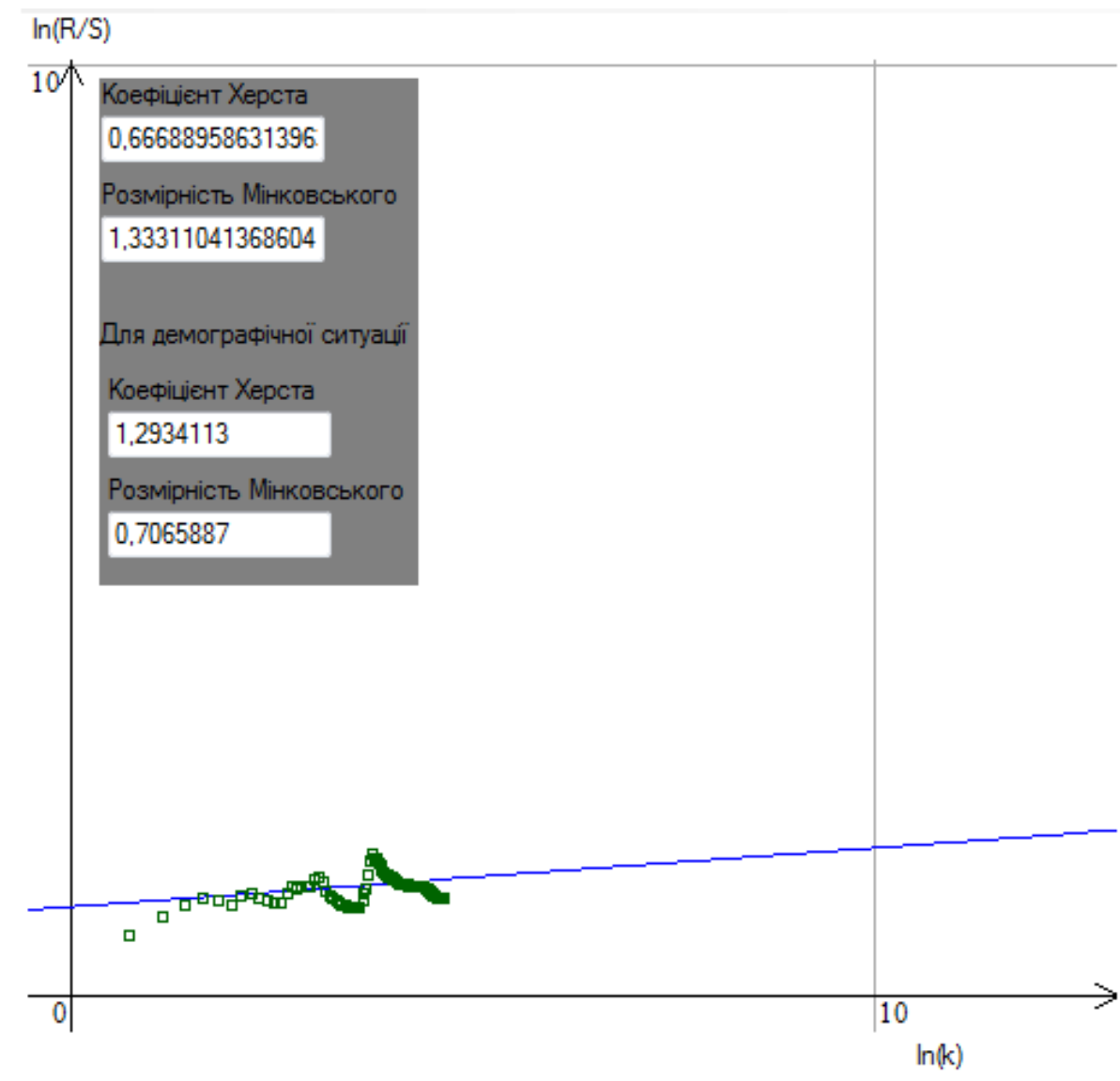

Рис. 3. Приклад розрахунку фрактальної розмірності класичним R/Sметодом для соціально-економічних процесів

Таким чином, проведений аналіз показав, що величина фрактальної розмірності $\mathrm{D} \epsilon$ кількісним критерієм оцінки нелінійності часового ряду валютного курсу, а для iї визначення було використано класичний R/S-метод.

Найпростішим способом прогнозування ринкової ситуації є екстраполяція, тобто поширення тенденцій, що склалися в минулому, на майбутнє. Сформовані об'єктивні тенденції зміни економічних показників до певної міри зумовлюють їх величину в майбутньому. До того ж багато ринкових процесів характеризуються деякою інерційністю. Особливо це проявляється в короткостроковому прогнозуванні. У той же час прогноз на віддалений період повинен максимально враховувати ймовірність зміни умов, в яких буде функціонувати ринок. 
Класичні методи екстраполяції та апроксимації, до яких відносять метод найменших квадратів, метод Лагранжа, методи Гауса тощо, дають погані результати моделювання та прогнозування. Це пов'язано 3 тим, що в якості вихідних даних використовується великий обсяг статичних даних (а саме, курс долара до гривні за 2008 рік як більш-менш стабільний). Обрані методи екстраполяції не дають можливості моделювати тренд, бо при великий кількості базових точок, яка швидко зростає, дають дуже великі осциляції та похибки обчислення (рис. 4).

У зв'язку з цим було запропоновано використати фрактальний метод плаваючої середньої та його модифікації: метод зміщених плаваючих середніх, метод експоненціальних плаваючих середніх та метод врівноважених плаваючих середніх, а також їх комбінації.

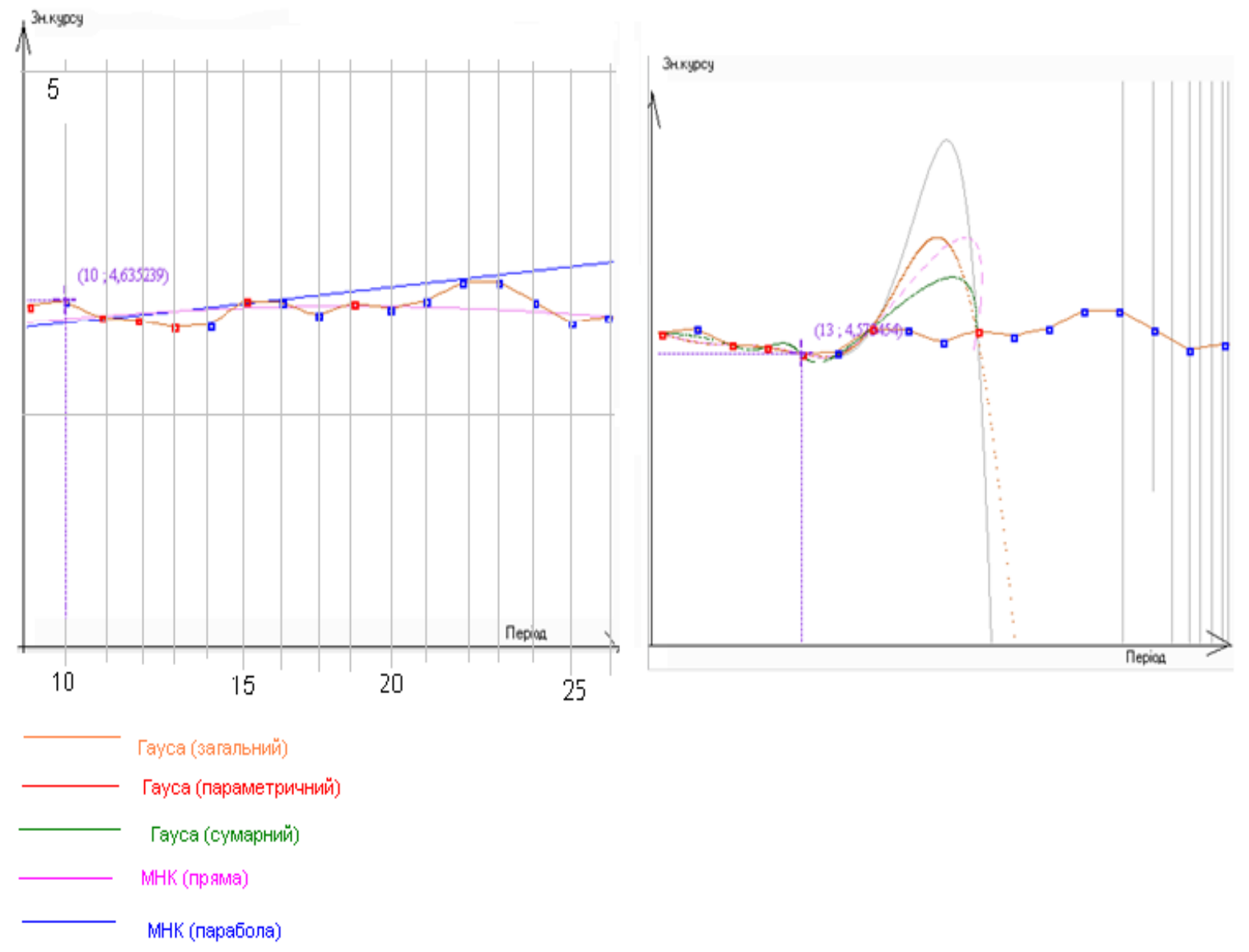

Рис. 4. Результати графічного аналізу класичних методів моделювання

Методи плаваючої середньої. Плаваюча середня - інструмент згладжування часових рядів, що застосовується для відображення змін біржових котирувань акцій, цін на сировину, курсів валют тощо. Найбільш широко використовуються на практиці прості, зважені та експоненціальні плаваючі середні. Проста плаваюча середня визначається як середня ціна закриття за останні $\mathrm{N}$ днів. 
Як правило, плаваючі середні розраховуються на основі цін закриття. Тим не менш, можна розраховувати плаваючі середні цін відкриття, максимумів, мінімумів, а також середніх значень денних цін відкриття, (включаючи поточний день). Термін «плаваюча середня» означає, що набір усереднених значень безперервно рухається в часі. Плаваюча середня відображає тенденцію зміни цін і згладжує їх несуттєві коливання. Якщо на ринках з вираженою тенденцією плаваючі середні працюють добре, то на тих ринках, де вираженого тренда немає, плаваючі середні дають багато помилкових сигналів.

Плаваючі середні різних типів відрізняються тим, що в них застосовуються різні вагові коефіціснти, які присвоюються останнім даним. У разі простої плаваючої середньої (SMA) всі ціни розглянутого періоду мають однакову вагу.

Зміни цінової тенденції розпізнаються по перетину кривих МА трендом. Оскільки перетини ціною кривої МА дають чітку інформацію про необхідність покупки або продажу, це сприяє позбавленню від суб'єктивізму при побудові й інтерпретації трендових ліній.

Перевагою $\epsilon$ те, що МА може бути застосована до аналізу практично будьякої інформації, що відображає зміну в часі елементів ринкової структури (за допомогою МА можна аналізувати і осцилятори).

Головний недолік МА в тому, що вона реагує на одне редагування курсу два рази: при отриманні значення i при його вибутті 3 розрахунку. Ще один з недоліків МА полягає в деякому запізнюванні сигналів. Якщо період дії тенденції незначний, то можливі збитки.

Для усунення недоліків попередніх методів було запропоновано адаптивний метод плаваючої середньої, який є комбінацію розглянутих вище методів.

На рисунку 5 показано етапи роботи адаптивного методу плаваючої середньої:

1. Розбиваємо заданий тренд на розрахункові та тестові точки. Проводимо моделювання на основі розрахункових точок, похибку перевіряємо на тестових.

2. Розбиваємо послідовність на $\mathrm{n}$ інтервалів. Таким чином, обираємо період згладжування. Величину п обирає користувач.

3. На першому інтервалі (відрізку) проводимо моделювання чотирма методами плаваючої середньої. В результаті отримуємо чотири прямі.

4. Обчислюємо похибку кожного з методів. Нехай перший метод (на рисунку 5 позначено жирною прямою [1' , 2' ]) дав найменшу похибку, тоді ця пряма використовується для прогнозування на наступному відрізку. Якщо різниця між прогнозованим та дійсним значеннями у тестовій точці не перевищує деякого наперед заданого $\delta$, то ця пряма екстраполюється i на наступний відрізок. Якщо різниця більша за $\delta$, то на другому відрізку знову будуються чотири прямі.

5. Пряма, отримана на останньому відрізку, використовується для обчислення прогнозного значення. 
За результатами роботи алгоритму адаптивного методу та порівняння похибок інших методів були отримані дані, що зображено на рисунку 6.

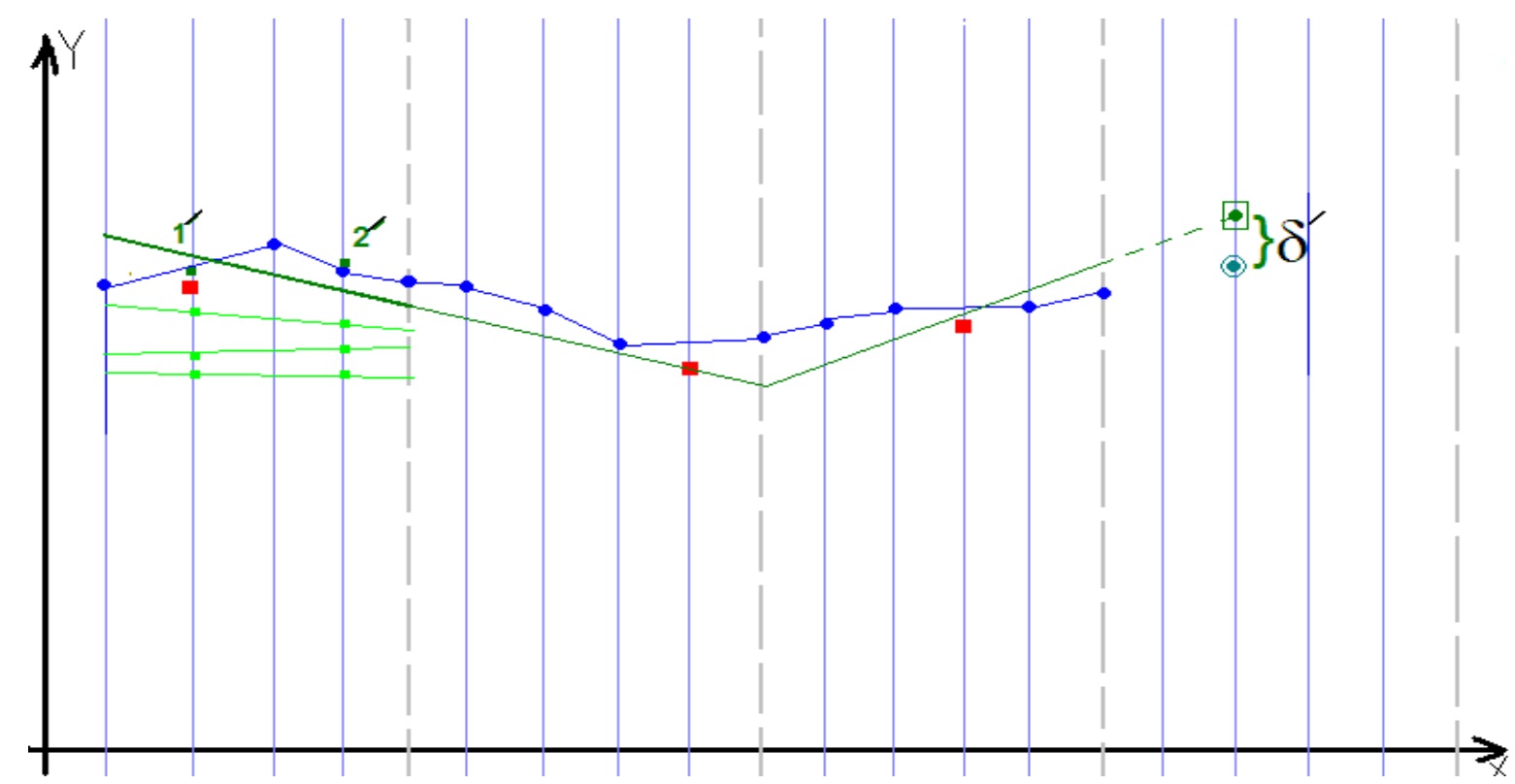

Рис. 5. Етапи роботи алгоритму адаптивного методу плаваючої середньої

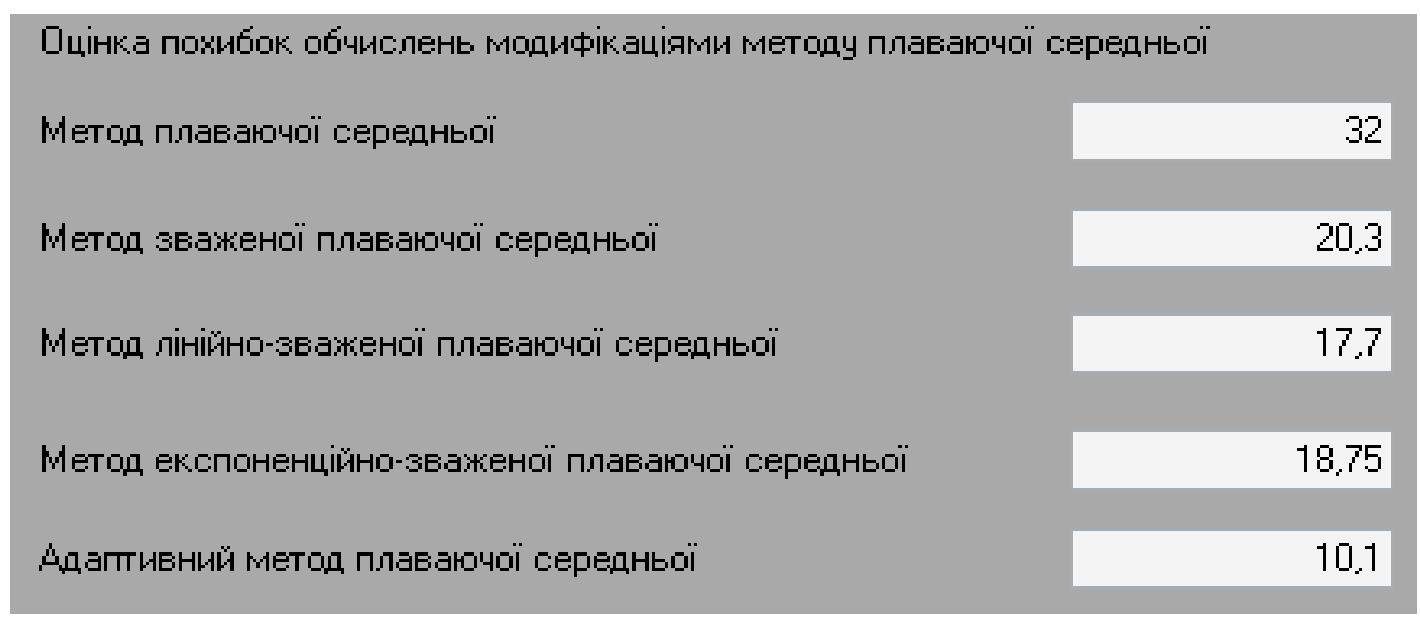

Рис. 6. Похибки обчислень курсу валюти (\%)

Відповідність отриманих результатів реальним за перевірочною вибіркою визначається похибкою обчислень. 3 наведених даних видно, що максимальну похибку при обчисленні прогнозу валютного курсу дає використання методу плаваючої середньої (біля 32\%), а найменшу - адаптивний метод (біля 10\%). Таким чином, 3 проведеного аналізу можна зробити висновок, що для прогнозування коливань курсів валют доцільно використовувати запропонований адаптивний метод, який $\epsilon$ комбінацією методів прогнозування плаваючої середньої. 
Висновки. В результаті проведеного дослідження було виявлено, що деякі соціально-економічні процеси не підлягають прогнозуванню класичними поліноміальними методами. Було обгрунтовано, що такі процеси мають фрактальну структуру, і для їх моделювання необхідно застосовувати методи фрактальної геометрії . Було порівняно сумарні середньоквадратичні похибки розрахунків різними методами прогнозування та зроблено висновок, що удосконалений метод плаваючої середньої дає найменшу похибку.

Наукова новизна полягає в обгрунтуванні використання геометричних методів для прогнозування динаміки економічних процесів. Для графіку коливань курсу валют було визначено фрактальну розмірність, яка склала 1.333 , що свідчить про те, що на систему впливає одна або кілька сил, що рухають систему в одному напрямку. Було вдосконалено метод плаваючої середньої за рахунок порівняння результатів на кожному кроці, що дозволило підвищити точність розрахунків. Набуло подальшого розвитку застосування теорії хаосу для прогнозування динаміки економічних процесів.

Теоретична значимість дослідження полягає в обгрунтуванні ефективності використання нових способів прогнозування, а саме методів фрактальної геометрії в цілях розрахунку прогнозу зміни курсу валют. Результати дослідження розвивають теоретичні уявлення в галузі прогнозування та моделювання економічних процесів, а також можуть бути використані для подальшої наукової розробки методів прогнозування поведінки інших економічних процесів.

Практична значимість роботи визначається прикладним характером проведених досліджень, іiі практичною спрямованістю. Запропоновані алгоритми розрахунку графіку кривої курсу валют, обчислення похибки та інших показників проводились за допомогою комп'ютерної системи. Така система дає змогу проводити комп'ютерний експеримент, що дозволяє наочно бачити результати роботи. А це, в свою чергу, спрощує роботу фахівців в сфері аналізу динаміки економічних процесів.

\section{Література:}

1. Янч Э. Прогнозирование научно-технического прогресса: пер. с англ. / Э. Янч, общ. ред. и предисл. Д.М. Гвишиани. — М.: Прогресс, 1974. — 586 с.

2. Бестужев И.В. Рабочая книга по прогнозированию / Редкол.: И.В. Бестужев-Лада. М.: Мысль, 2008. - 430 с.

3. Рой О.М. Исследование социально-экономических и политических процессов / О.М. Рой. - СПБ.: Питер, 2004. - С. 22.

4. Чекулаев М. Риск-менеджмент: управление финансовыми рисками на основе анализа волатильности / М.Чекулаев // М.: Альпина Паблишер, 2002. - 344 с.

5. Якимкин В. Фундаментальній анализ / В. Якимкин // М.: Омега-Л, 2008. 640 с.

6. Siegel I.H. Technological Change and Long-Run Forecasting / I.H.Siegel // The Journal of Business of the University of Chicago, Vol.26, № 3, July 1953. - Chicago. - P. 141-156.

7. Статистическое моделирование и прогнозирование. Учебное пособие / Под ред. А.Г. Гранберга. - М.: Финансы и статистика, 1990. - 174 с.

8. Божокин С.В. Фракталы и мультифракталы / С.В. Божонкин, Д.О. Паршин - Ижевск: НИЦ «Регулярная и хаотическая динамика», 2001. - 128 с. 
9. Кривда О.В. Механізм ризик-менеджменту та чинники, що його формують / О.В. Кривда // Економічний вісник Національного технічного університету України "Київський політехнічний інститут” [Текст]: Зб. наук. праць. - Вип. 10. - К:НТУУ «КПІ», 2013. - С. 268-273.

10. Сидоренко Ю. В. Проблеми обчислювання симплексної вагової інтерполяційної функції / О. С. Каленюк, Ю. В. Сидоренко // Міжвідомчий науково-технічний збірник «Прикладна геометрія та інженерна графіка». - 2010. - Вип. 85. - С. 164-167.

11. Кликушин Ю.Н. Фрактальная шкала для измерения формы распределений вероятности / Ю.Н. Кликушин // Журнал радиоэлектроники № 3, 2000. - С. 15-18. 